\title{
NOTE
}

\section{Characteristics of Flexibacter psychrophilus isolated from Atlantic salmon in Australia}

\author{
L. M. Schmidtke, J. Carson*
}

Fish Health Unit, Department of Primary Industry and Fisheries, PO Box 46, Kings Meadows, Tasmania 7249 , Australia

\begin{abstract}
Flexibacter psychrophilus (syn. Cytophaga psychrophila) was isolated in Tasmania, Australia, from farmed Atlantic salmon Salmo salar with moderate to severe erosion of the fins; there was no evidence of skin lesions. The mortality level in the population of affected fish was less than $0.01 \% \mathrm{wk}^{-1}$, but the morbidity level was in excess of $80 \%$. The phenotype of the Australian isolates is in good agreement with strains from Europe and North America and differs only in that the Australian isolates produced a brown pigmentation on tyrosine agar and did not hydrolyse Tween 80 . The growth in vitro of all isolates was inhibited by acriflavine, ampicillin, and oxolinic acid at concentrations in excess of $0.5 \mu \mathrm{g} \mathrm{ml}^{-1}$ and by oxytetracycline at $1.56 \mathrm{\mu g} \mathrm{ml}^{-1}$; none of the isolates were inhibited by sulphamethazine or trimethoprim at $25 \mathrm{\mu g} \mathrm{ml}^{-1}$.
\end{abstract}

KEY WORDS: Flexibacter psychrophilus - Fin rol A Atantic salmon Salmon salar Antibiotic sensitivity

Filamentous bacteria belonging to the FlexibacterCytophaga Complex (FCC) are well recognized fish pathogens, with marine and freshwater species capable of causing disease. Flexibacter columnaris has been reported as a pathogen of freshwater fish throughout the world (Austin \& Austin 1987), while accounts of $F$. maritimus infection of sea farmed fish have been made in Japan (Wakabayashi et al. 1986), Scotland (Bernardet et al. 1990), and Spain (Alsina \& Blanch 1993). Cytophaga psychrophila, re-classified as F. psychrophilus (Bernardet \& Grimont 1989), is the agent of coldwater disease in salmonids and may cause a spectrum of pathologies ranging from ulcerative skin necrosis to systemic infection involving major body organs. F. psychrophilus is the cause of significant levels of mortality in coho salmon Oncorhynchus kisutch

-Addressee for correspondence hatcheries of the USA and Canada (Holt et al. 1993) and is also recognized as the detiological agent of rainbow trout $O$. mykiss 'fry mortality syndrome' in France, Denmark, the United Kingdom, Germany, Spain, and Finland (Bernardet \& Kerouault 1989, Lorenzen et al. 1991, Austin 1992, Bruno 1992, Santos et al. 1992, Dalsgaard 1993, Toranzo \& Barja 1993, Wiklund et al. 1994). Other FCC bacteria associated with fish disease are F. ovolyticus, a pathogen of Atlantic halibut Hippoglossus hippoglossus eggs and larvae (Hansen et al. 1992), C. johnsonae, a putative pathogen of barramundi Lates calcarifer (Carson et al. 1993), and $C$. aquatilis (Strohl \& Tait 1978). In addition, unidentified FCC bacteria have been described as causes of fish disease in the USA (Kent et al. 1988), Scotland (Mudarris \& Austin 1989), and Germany (Hilger et al. 1991). The majority of reports of FCC bacteria causing disease are derived from the northern hemisphere. This report describes the characteristics of $F$ : psychrophilus isolated from Atlantic salmon in Australia, a biogeographically isolated region in the southern hemisphere.

Materials and methods. Diseased Atlantic salmon Salmo salar were obtained from a commercial fish hatchery in Tasmania, Australia, operating with flowthrough tanks fed with river water Fish had a body weight between 44 and $47 \mathrm{~g}$ and were held at a stocking density of 23 to $25 \mathrm{~kg} \mathrm{~m}^{-3}$. At the time of sampling, the water temperature was $5^{\circ} \mathrm{C}$ and had ranged between 2 and $9^{\circ} \mathrm{C}$ over the previous 3 mo. Routine grading for size 2 mo prior to sampling and low water temperatures were the only identifiable stress factors (Elliott 1981) preceding evidence of disease.

A total of 30 fish with eroded fins and/or tails were examined. The presence of pathogens other than FCC bacteria was determined by aseptically collecting 
kidney tissue by pipette and culturing on Blood Agar Base No. 2 (CM271, Oxoid, Basingstoke, UK) supplemented with $7 \%$ (v/v) defibrinated sheep's blood. Eroded fins and tails were sampled by scraping the margin of the lesion with a sterile scalpel blade; the collected material was then inoculated onto freshwater Ordal's agar (FOA) (Anacker \& Ordal 1959). Agar plates were incubated at $14^{\circ} \mathrm{C}$ for up to $10 \mathrm{~d}$.

Characterization of FCC bacteria was made using tests described previously (Carson et al. 1993) and by the use of additional procedures as outlined; incubation of all tests was made at $18^{\circ} \mathrm{C}$. Cell length of 10 representative isolates was determined after 3,7 , and $17 \mathrm{~d}$ incubation by measuring Gram stained bacteria grown in Shieh's broth (SB) (Song et al. 1988); 10 cells per isolate were measured to calculate a mean length; a grand mean cell length was calculated for each time interval. Catalase activity was determined by the coverslip method of Taylor \& Achanzar (1972) and by adding several drops of $3 \%(\mathrm{v} / \mathrm{v})$ hydrogen peroxide to a dense suspension of bacteria in $1 \%(\mathrm{v} / \mathrm{v})$ Tween $80 \mathrm{aq}$.; oxidase reaction was determined by the method of Kovac (Cowan 1974) and by DrySlide Oxidase (Difco Laboratories, Detroit, MI, USA). Production of $\mathrm{H}_{2} \mathrm{~S}$ was detected with lead acetate strips suspended above SB supplemented with $0.01 \%$ (w/v) L-cysteine; Congo Red reaction was tested by the method of McCurdy (1969) using $0.001 \%$ (w/v) Congo Red; anaerobic growth was tested on FOA supplemented with $1.0 \%$ (w/v) $\mathrm{NaHCO}_{3}$ and $1.0 \%$ (w/v) glucose (Reichenbach 1989): lecithinase production was tested on FOA supplemented with $0.5 \%(\mathrm{v} / \mathrm{v})$ sterile egg yolk with precipitation of fatty acids extending from the colony margin recorded as a positive reaction. Gliding motility was determined for 10 isolates by adapting a procedure described by Perry (1973): sterile slides were coated with a thin Iayer of FOA, inoculated with a single central longitudinal line, and incubated in a sterile Petri dish for $3 \mathrm{~d}$. A cover slip was placed directly onto the line of bacterial growth and gliding motility was then determined by examining bacteria with phase contrast microscopy and a standard focal length $\times 40$ phase objective. The minimum inhibitory concentrations (MIC) of neutral acriflavine, ampicillin, oxolinic acid, oxytetracycline, sulphamethazine, and trimethoprim were determined by microbroth dilution in SB (Carson et al. 1993).

Results. Nearly all fish on the affected farm had eroded fins, ranging in severity from ragged margins to complete loss of the fin (Fig, 1). The most severely affected fins were the pectoral and pelvic fins and to a lesser extent the dorsal fin. Involvement of the caudal fin was infrequent but where it occurred the fin had evanesced and advancing erosion of the caudal peduncle musculature was evident. Although the level

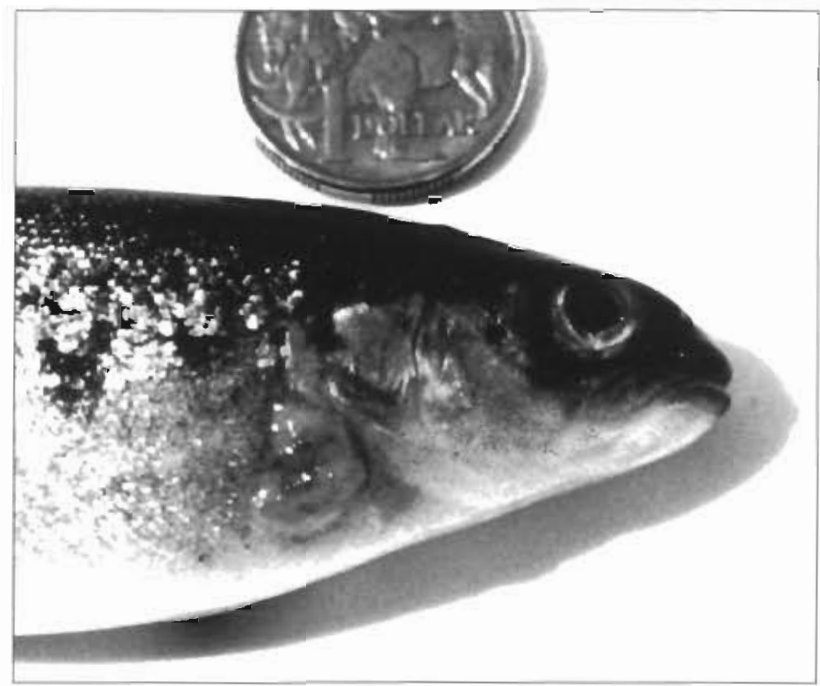

Fig. 1. Salmo salar, Atlantic salmon with severely eroded pectoral fin. Flexibacter psychrophilus was isolated from eroded fins of 27 out of 30 fish sampled. Despite a high level of morbidity amongst affected fish, mortalities were less than

$0.01 \% \mathrm{wk}^{-1}$ The coin shown has a diameter of ca $25 \mathrm{~mm}$

of morbidity was high, the mortality level was less than $0.01 \%$, a level of attrition considered to be commercially acceptable. No bacteria were recovered in culture on blood agar from kidney of the 30 fish selected for examination, indicating the systemic absence of non-FCC-type bacteria, but from 27 of the fish, small deep-yellow-coloured colonies were isolated on FOA from eroded fins. The colonies were 1 to $2 \mathrm{~mm}$ in diameter with a smooth appearance and did not adhere to the agar; most colonies had an entire edge but a proportion had a narrow border of flat rhizoid growth. Characterization was undertaken for 20 isolates and these bacteria were identified as Flexibacter psychrophilus according to the attributes listed in Table 1. Attempts were made to detect gliding motility in wet preparations made from broth cultures but these were unsuccessful. Gliding was detected relatively easily by slide culture; however, even by this method, the rate of travel was slow. Motion was detected by noting the position of cells with reference to the rulings on an eyepiece graticule and making observations over a period of $5 \mathrm{~min}$. Mean cell lengths of F psychrophilus after 3,7 , and $17 \mathrm{~d}$ were 3,4 , and $7 \mu \mathrm{m}$, respectively. The oxidase reaction, either by Kovac's method or by DrySlide Oxidase, was readily detectable in all isolates of F psychrophilus and had a rate of reaction and intensity of colour similar to those of $F$. columnaris. The catalase reaction was very weak and was only detected convincingly by the coverslip method; no reaction was seen with the Tween 80 method. The MIC of selected antibacterials for 10 strains of $F$ psychrophilus are given in Table 2 . 
Table 1 Phenotype of Flexibacter psychrophilus isolated from Atlantic salmon Salmo salar in Australia and of strains from Europe and North America. Data as percentage of strains positıve; w: weak reaction; $V$ variable reaction

\begin{tabular}{|c|c|c|c|c|c|}
\hline Test & $\begin{array}{l}\text { Australian } \\
\text { 1solates }\end{array}$ & Pacha (1968) & $\begin{array}{c}\text { Bernardet \& } \\
\text { Kerouault (1989) }\end{array}$ & $\begin{array}{l}\text { Lehmann et } \\
\text { al. (1991) }\end{array}$ & $\begin{array}{l}\text { Holt et al. } \\
\text { (1993) }\end{array}$ \\
\hline No. of strains & 20 & 10 & 7 & 7 & 28 \\
\hline Gliding motility & 100 & 100 & 100 & 100 & 100 \\
\hline Catalase & $100 \mathrm{w}$ & 100 & $100 \mathrm{w}$ & $100 w$ & $100 \mathrm{w}$ \\
\hline Oxudase & 100 & 0 & $100 \mathrm{w}$ & 100 & 0 \\
\hline Congo Red reaction & 0 & & 0 & 0 & \\
\hline Flexirubin reaction & 100 & & 100 & 100 & 100 \\
\hline Glucose acid & 0 & 0 & 0 & & 0 \\
\hline $\mathrm{H}_{2} \mathrm{~S}$ formation & 0 & 0 & 0 & 0 & 0 \\
\hline Nitrate reduction & 0 & 0 & 0 & 0 & 0 \\
\hline Tyrosine pigmentation & 100 & & 0 & 0 & \\
\hline \multicolumn{6}{|l|}{ Growth: } \\
\hline Anaerobic & 0 & & 0 & 0 & 0 \\
\hline $25^{\circ} \mathrm{C}$ & 90 & & 100 & 100 & 64 \\
\hline $30^{\circ} \mathrm{C}$ & 0 & & 0 & 0 & 0 \\
\hline $\mathrm{NaCl} 0.5 \%$ & 100 & 100 & 100 & & 100 \\
\hline $\mathrm{NaCl} 1.0 \%$ & 0 & 60 & 0 & & 100 \\
\hline \multicolumn{6}{|l|}{ Hydrolysis: } \\
\hline Casein & 100 & 100 & 100 & 100 & 100 \\
\hline Chitin & 0 & 0 & 0 & 0 & 0 \\
\hline DNA & 100 & & 100 & 100 & \\
\hline Gelatin & 100 & 100 & 100 & 100 & 100 \\
\hline Lecithin & 100 & & 100 & 100 & \\
\hline ONPG & 0 & & 0 & 0 & \\
\hline Starch & 0 & 0 & 0 & 0 & 0 \\
\hline Tributyrin & 100 & 100 & 100 & 100 & 100 \\
\hline Tween 20 & 100 & & 100 & 100 & \\
\hline Tween 40 & 100 & & & & \\
\hline Tween 60 & 100 & & & & \\
\hline Tween 80 & 5 & & 100 & 100 & \\
\hline Tyrosine & 100 & 20 & 100 & 100 & $\mathrm{~V}$ \\
\hline Urea & 5 & & & & \\
\hline
\end{tabular}

Discussion. The phenetic characters determined in this study of 20 isolates of Flexibacter psychrophilus are in good agreement with published data for this taxon (Pacha 1968, Bernardet \& Kerouault 1989, Lehmann et al. 1991, Holt et al. 1993). Cytochrome oxidase was readily detected in the Australian isolates and this is in agreement with Bernardet \& Kerouault (1989), who were able to detect this enzyme in American and European isolates. Both Pacha (1968) and Holt et al.

Table 2. Minimum inhibitory concentrations (MIC) of selected antibacterial agents for 10 strains of Flexibacter psychrophilus isolated from Atlantic salmon Salmo salar in Australia

\begin{tabular}{|lc|}
\hline Antibacterial & MIC $\left(\mu \mathrm{g} \mathrm{ml}{ }^{-1}\right)$ \\
\hline Acriflavine & $0.20-0.39$ \\
Ampicillin & $0.05-0.10$ \\
Oxolinic acid & $0.05-0.10$ \\
Oxytetracycline & $0.78-1.56$ \\
Sulphamethazine & $>25$ \\
Trimethoprim & $>25$ \\
\hline
\end{tabular}

(1993) were unable to detect oxidase activity but concluded that the different reactions for this test obtained by various investigators may be the result of using assay procedures of different sensitivities. The catalase reaction for the Australian isolates of $F$. psychrophilus was weak and this is consistent with reports made by Bernardet \& Kerouault (1989) and Holt et al. (1993) None of the isolates were able to grow in $\mathrm{FOB}$ with $1 \%$ $\mathrm{NaCl}$ although Holt et al. (1993) were able to grow their isolates at this $\mathrm{NaCl}$ concentration using tryptone yeast extract salts (TYES) medium. These authors note that F. psychrophilus grows best in Shieh's and TYES media which suggests that medium composition is important when testing growth characteristics at the limits of the physiological range for the species. The Australian isolates had some characteristics at variance with the reported phenotypes of F. psychrophilus. Hydrolysis of short chain length Tweens was observed for all the Australian isolates, in agreement with findings made by Bernardet \& Kerouault (1989) and Lehmann et al. (1991); however, only 1 Australian isolate was able to hydrolyse Tween 80 while all the European 
and American isolates tested could degrade this substrate. The remaining difference noted was the ability of the Australian isolates to produce a brown pigmentation when growing on media enriched with tyrosine, a characteristic of F. psychrophilus not detected by either Bernardet \& Kerouault (1989) or Lehmann (1991). The cell length of young cultures of the Australian isolates are within the range reported for the species (Holt et al. 1993) but it is interesting to note that with advancing age, cell length increases. Cell elongation with age is seen in other FCC bacteria and in particular members of the genus Cytophaga as defined by Reichenbach (1989).

Oxytetracycline is considered to be the antibiotic of choice for control of infection by Flexibacter psychrophilus in coho salmon while only partial control is achievable with sulphonamides such as sulphisoxazole and sulphamethazine (Holt et al. 1993). The MIC data for the Australian isolates of $F$. psychrophilus indicate that ampicillin and oxolinic acid are particularly active, while the MIC range of 0.78 to $1.56 \mu \mathrm{g} \mathrm{ml}^{-1}$ for oxytetracycline suggests that only partial control could be achieved with this antibiotic. The resistance of all the Australian isolates of $F$. psychrophilus to sulphamethazine indicates that control is unlikely to be achieved with this antibiotic and is further evidence of the unsuitability of sulphonamides for controlling infection.

The known geographic distribution of Flexibacter psychrophilus, once thought to be limited to North America, has increased steadily with recent reports from several European countries (Dalsgaard 1993) and Japan (Wakabayashi et al. 1991). Holt et al. (1993) predicted that $F$. psychrophilus was likely to be found in most temperate salmonid producing regions in the world, and so it is perhaps not surprising that this pathogen has now been recovered from diseased fish in a cool climate region of Australia. The origin of these Australian isolates of $F$. psychrophilus is interesting in view of the limited number of importations of salmonids. Atlantic salmon ova, conserved during shipping by the melt water of ice obtained from Wenham Lake near Boston, Massachusetts, USA. (Walker 1988), were first imported to Tasmania from Great Britain in 1864. Breeding populations of Atlantic salmon failed to develop in rivers and lakes but by 1895 both rainbow trout and brown trout Salmo trutta had been successfully introduced and naturalized. The current Tasmanian population of Atlantic salmon for aquaculture was obtained between 1984 and 1986 as disinfected ova from disease free, landlocked fish at Gaden in New South Wales, Australia (Hortle 1988). Whether F. psychrophilus was naturally present in the aquatic environment of Tasmania prior to the importation of salmonids or was introduced with ova and melting ice water during attempts at naturalization is uncertain. Ribotyping or randomly amplified polymorphic DNA (RAPD) analysis of isolates from North America and Australia may help to establish the provenance of the Australian strains of F. psychrophilus.

The epizootiology of the pathogen in Australia contrasts with infection elsewhere, where it is seen as a cause of significant mortality in juvenile salmonids, particularly coho salmon and rainbow trout. In this first report from Australia, Flexibacter psychrophilus has been isolated only from Atlantic salmon with eroded fins in pre-smolt fish held under cold stress conditions. The role of the pathogen as an agent of fin erosion remains putative for the time being because no experimental challenges were undertaken in this study. The apparent lack of virulence of these Australian isolates may be a characteristic of the strains or may simply reflect the resistance of Atlantic salmon to infection. with F. psychrophilus. Further work is required to characterize the virulence determinants of the Australian isolates and compare them with aggressins of virulent strains of $F$ psychrophilus from other geographic regions.

Acknowledgements. The Fish Health Unit is funded by the State Government of Tasmania, Australia, with generous support from Salmon Enterprises of Tasmania P/L.

\section{LITERATURE CITED}

Alsina M, Blanch AR (1993) First isolation of Flexibacter maritimus from cultivated turbot (Scophthalmus maximus). Bull Eur Ass Fish Pathol 13:157-160

Anacker RL, Ordal EJ (1959) Studies on the myxobacterium Chondrococcus columnaris. I. Serological typing. J Bacteriol 78:25-32

Austin B (1992) The recovery of Cytophaga psychrophila from two cases of ranbow trout (Oncorhynchus mykiss Walbaum) fry syndrome in the UK. Bull Eur Ass Fish Pathol 12:207-208

Austin B, Austin DA (1987) Bacterial fish pathogens: disease in farmed and wild fish. Ellis Horwood Ltd, Chichester

Bernardet JF, Campbell AC, Buswell JA (1990) Flexibacter maritimus is the agent of 'black patch necrosis' in Dover sole in Scotland. Dis aquat Org 8:233-237

Bernardet J-F، Grimont PAD (1989) Deoxyribonuclelc acid relatedness and phenotypic characterization of Flexibacter columnans sp. nov, nom. rev., Flexibacter psychrophilus sp. nov., nom. rev., and Flexibacter maritimus Wakabayashi, Hikida and Masumura 1986. Int J syst Bacteriol 39:346-354

Bernardet J-F, Kerouault B (1989) Phenotyplc and genomic studies of Cytophaga psychrophila isolated from diseased rainbow trout (Oncorhynchus mykiss) in France. Appl environ Microbiol 55:1796-1800

Bruno DW (1992) Cytophaga psychrophila (= Flexibacter psychrophlus) (Borg), Histopathology associated with mortalities among farmed rainbow trout, Oncorhynchus mykiss (Walbaum) in the UK. Bull Eur Ass Fish Pathol $12: 215-216$ 
Carson J, Schmidtke LM, Munday BL (1993) Cytophaga johnsonae: a putative skin pathogen of juvenile farmedbarramundi, Lates calcarifer Bloch. J Fish Dis 16:209-218

Cowan ST (1974) Manual for the identification of medical bacteria, 2nd edn. Cambridge University Press, Cambridge

Dalsgaard I (1993) Virulence mechanisms in Cytophaga psychrophila and other Cytophaga-like bacteria pathogenic for fish. A Rev Fish Dis 3:127-144

Elliott JM (1981) Some aspects of thermal stress on freshwater teleosts. In: Pickering AD (ed) Stress and fish. Academic Press, London, p 209-245

Hansen $G H$, Bergh $\varnothing$, Michaelsen J, Knappskog D (1992) Flexibacter ovolyticus sp. nov., a pathogen of eggs and larvae of Atlantic halibut. Hippoglossus hippoglossus L. Int $\mathrm{J}$ syst Bacteriol 42:451-458

Hilger I, Ullich S, Anders K (1991) A new ulcerative flexibacteriosis-like disease ('yellow pest') affecting young Atlantic cod Gadus morhua from the German Wadden sea. Dis aquat Org 11:19-29

Holt RA, Rohovec JS, Fryer JL (1993) Bacterial cold-water disease. In: Inglis V, Roberts RJ, Bromage NR (eds) Bacterial diseases of fish. Blackwell Scientific Publications, Oxford, p $3-22$

Hortle M (1988) The quarantine of Atlantic salmon (Salmo salar L.) in Tasmania, 1984-86. Technical report 29. Department of Sea Fisheries, Hobart

Kent ML, Dungan CF, Elston RA, Holt RA (1988) Cytophaga sp. (Cytophagales) infection in seawater pen-reared Atlantic salmon Salmo salar. Dis aquat Org 4:173-179

Lehmann J, Mock D, Stürenberg F-J, Bernardet J-F (1991) First isolation of Cytophaga psychrophila from a systemic disease in eel and cyprinids. Dis aquat Org $10: 217-220$

Lorenzen E, Dalsgaard I, From J, Hansen EM, Hørlyck V, Korsholm H, Mellergaard S, Olesen NJ (1991) Preliminary investigations of fry mortality syndrome in rainbow trout. Bull Eur Ass Fish Pathol 11:77-79

McCurdy HD (1969) Studies on the taxonomy of the Myxobacterales: I. Record of Canadian isolates and survey of methods. Can J Microbiol 15:1453-1461

Responsible Subject Editor: T Evelyn, Nanaimo, B.C., Canada
Mudarris M, Austin B (1989) Systemic disease in turbot Scophthalmus maximus caused by a previously unrecognised Cytophaga-like bacterium. Dis aquat Org 6:161-166

Pacha RE (1968) Characteristics of Cytophaga psychrophila (Borg) isolated during outbreaks of bacterial cold-water disease. Appl Microbiol 16:97-101

Perry LB (1973) Glidung motility in some non-spreading flexibacteria. J appl Bactenol 36:227-232

Reichenbach H (1989) Famıly I. Cytophagacae. In: Staley JT (ed) Bergey's manual of systematic bacteriology, Vol. 3. Williams \& Wilkins, Baltimore, p 2013-2050

Santos Y, Huntly PJ, Turnbull A, Hastings TS (1992) lsolation of Cytophaga psychrophila (Flexibacter psychrophilus) in association with rainbow trout mortality in the United Kingdom. Bull Eur Ass Fish Pathol 12:209-210

Song YL. Fryer JL, Rohovec JS (1988) Comparison of six media for the cultivation of Flexibacter columnaris. Fish Pathol 23:91-94

Strohl WR, Tait LR (1978) Cytophaga aquatilis sp. nov., a facultative anaerobe isolated from the gills of freshwater fish. Int J syst Bacteriol 28:293-303

Taylor WI. Achanzar D (1972) Catalase test as an aid to the identification of Enterobacteriacea. Appl Microbiol 24: $58-61$

Toranzo AE, Barja JL (1993) Fry mortality syndrome (FMS) in Spain. Isolation of the causative bacterium Flexibacter psychrophilus. Bull Eur Ass Fish Pathol 13:30-32

Wakabayashi H. Hikida M, Masumura K (1986) Flexibacter maritimus sp. nov, a pathogen of marine fish. Int $J$ syst Bacteriol 36:396-398

Wakabayashi H, Horiuchi M, Bunya T, Hoshiai G (1991) Outbreaks of cold-water disease in coho salmon in Japan. Gyobo Kenkyu (Fish Pathol) 26:211-212

Walker J (1988) Origins of the Tasmanian trout - an account of the salmon ponds and the first introduction of salmon and trout to Tasmania in 1864. Inland Fisheries Commission, Hobart

Wiklund T, Kaas K, Lömström L, Dalsgaard I (1994) Isolation of Cytophaga psychrophila (Flexibacter psychrophilus) from wild and farmed rainbow trout (Oncorhynchus mykiss) in Finland. Bull Eur Ass Fish Pathol 14:44-46

Manuscript first received: April 19, 1994

Revised version accepted: October 26, 1994 